Article

\title{
Economic News Releases and Financial Markets in South Africa
}

\author{
Konstantinos Gkillas ${ }^{1, * \mathbb{C}}$, Dimitrios Vortelinos ${ }^{2}$, Christos Floros ${ }^{3}$ and Athanasios Tsagkanos ${ }^{1}$ \\ 1 Department of Business Administration, University of Patras, 26504 Patras, Greece; atsagkanos@upatras.gr \\ 2 Lincoln Business School, University of Lincoln, Lincoln LN5 7AT, UK; dvortelinos@lincoln.ac.uk \\ 3 Department of Accounting and Finance, School of Management and Economic Sciences, \\ Hellenic Mediterranean University, 71004 Heraklion, Greece; cfloros@hmu.gr \\ * Correspondence: gillask@upatras.gr
}

Received: 20 November 2018; Accepted: 1 November 2019; Published: 8 November 2019

check for updates

\begin{abstract}
We examine the impact of economic news releases on returns, volatility and jumps of the stock and foreign exchange markets of South Africa. We also assess the impact of macroeconomic determinants. The dataset range is fifteen years covering the period from January, 2000 to December, 2014. Results are robust to different sub-periods before and after the global financial crisis of 2008 . Volatility is estimated with the use of the median realized variance estimator. Jumps are also detected. The impact of the announcements is assessed building using regression techniques. Returns, volatility and jumps of both stock and foreign exchange markets are significantly explained nationally by macroeconomic fundamentals and economic news releases.
\end{abstract}

Keywords: South Africa; economic news; macro fundamentals

JEL Classification: G15; G18; F38

\section{Introduction}

Investors are interested in any new information arrival in financial markets. The detection of any new information helps prediction. The most common type of such information is unexpected events causing stock market anomalies. Such events affect returns, dispersion (volatility) and discontinuities (jumps). This is why financial markets show unexpected behavior on days with economic news. McQueen and Roley (1993); Fleming and Remolona $(1997,1999)$ and Andersen et al. (2007), among others, studied whether economic news releases affect asset prices. These papers have showed strong evidence that macroeconomic announcement do affect financial markets. In particular, there are several studies that investigate the impact of economics news on financial markets (see Nowak et al. 2011; Rosa 2011; Marshall et al. 2012; Elder et al. 2012; Vortelinos and Gkillas 2018, among others). Other papers focused on financial announcements. Finnerty et al. (2013) examined the impact of credit ratings on five-year credit default swap (CDS) spreads. Fiordelisi et al. (2014) researched the impact of monetary policy decisions of the interbank market on banks between June 2007 and June 2012. Ricci (2015) assessed the impact of ECB monetary policy announcements on the price of large European banks. Kenourgios et al. (2015) examined the effects of quantitative easing announcements by the European Central Bank, the Bank of Japan and the Bank of England on exchange rate dynamics. The findings in several cases suggest that the economic announcements affect the investors' expectations. Furthermore, they also indicate that macroeconomic variables and macroeconomic announcements affect financial and commodity futures markets. Baum et al. (2015) examined the effect of macroeconomic news from China on other financial and commodity markets and found that Chinese macroeconomic announcements influence global markets. More specifically, 
Chinese macroeconomic announcements affect asset prices and move stock indices, foreign exchange, energy and industrial commodities. Cakan (2012) noted that inflation shocks and unemployment news affect stock and bond markets in different ways.

Cakan et al. (2014) analysed the impact of US macro announcements on emerging stock markets and found that US macroeconomic news do affect emerging stock markets. Shaikh and Padh (2013) investigated Indiaś VIX response to macroeconomic announcements, considering various macroeconomic indicators and noted that Indiaś VIX is responsive to several indicators. According to other studies (see e.g., Hausman and Wongswan 2011), US macroeconomic news have an impact on emerging markets. Moreover, Balcilar et al. (2017) noted that US macroeconomic news of inflation and unemployment affect the returns and volatility of the emerging Asian stock markets considered. Shu et al. (2018) found that Chinese equity, bond and currency markets influence other Asian stock markets during US stress and non-stress periods. Bahloul and Gupta (2018) analysed the impact of macroeconomic news surprises for Canada, the Euro area, Japan, the UK and the US related to returns and volatility for West Texas Intermediate and Brent crude oil futures. Bauwens et al. (2005) and Hashimoto and Ito (2010) examined how markets in developed countries respond to European and Japanese macroeconomic announcements. In particular, they examined whether changes in asset prices can be explained by fundamental factors. Hashimoto and Ito (2010) found that, actually, macroeconomic statistics news have a significant effect and can explain changes in asset prices, showing that price volatility increases after such announcements. De Pooter et al. (2014) examined inflation expectations for Brazil, Chile and Mexico, based on Chinese macroeconomic announcements (consumer price index (CPI), gross domestic product (GDP), industrial production (INP), PMI, retail sales and trade balance). However, they found that Chinese announcements do not affect the one-year nominal rate in these countries. After examining the relationship between oil prices and economics news, Elder et al. (2012) found that oil prices respond to macroeconomic announcements. Furthermore, Boudoukh et al. (2007) noted that there is a link between futures market and fundamentals, showing that several factors, such as market microstructure effects and news about Brazil, have an impact on prices. Finally, regarding the continent of Africa, there are very few studies to investigate the impact of economic news on financial markets. Gupta and Reid (2013) examined the sensitivity of a range of industry-specific South African stock market indices to monetary policy and macroeconomic news by applying a Bayesian vector autoregressive model. Esin and Gupta (2017) studied the impact of US macroeconomic announcement surprises on the volatility of the South African equity market by employing parametric estimation techniques. Gkillas et al. (2018a) examined the impact of South African economic news on Botswana, Egypt, Kenya and Mauritius in both stock and exchanges markets via an Asymmetric Power Arch model.

Previous studies examining emerging markets (including South Africa) on this issue are quite scattering. Furthermore, none of the previous studies investigates the impact of South Africa macroeconomic news on realized volatility. Volatility is a focal point in finance, as is the case with asset management and portfolio risk management, especially in emerging markets, which are considered to be more volatile. Nevertheless, volatility is a latent variable. It can be estimated using parametric and non-parametric techniques. However, any non-parametric estimator estimates quadratic variation, which is viewed as a better estimator for latent volatility. Furthermore, little research has been conducted so far to investigate the impact of economic news releases in realized volatility, while the existing literature has not studied the impact of economic news releases and macroeconomic determinants on volatility jumps in the South African financial markets so far. Jumps are important for portfolio risk management and asset allocation, since they add a source of risk in volatility, which is not easily subject to prediction. Furthermore, jumps can help the forecasting of equity risk premium (see Santa-Clara and Yan 2010), variance risk premium (see Li and Zinna 2018), returns (see Andersen et al. 2015) and volatility (see Duong and Swanson 2015). Previous studies on the impact of macroeconomic news have mainly focused on the first and second moment of the prices process -mostly estimated by parametric techniques- especially for advanced financial markets. On methodological 
grounds, we provide an econometric understanding of returns, realized volatility and jumps applying a vector autoregressive model with exogenous variables for the first time in South Africa. Thus, our study has two aims. The first one is to exploit the magnitude of macroeconomics announcements in order to explain returns, volatility and jumps. The second one is to investigate the extent to which these announcements can be extended to both equity and exchange rate markets. Such evidence can provide implications for investors and policymakers in South Africa.

We focus especially on the South African economy which is one of the wealthiest countries in Africa receiving a high level of interest as an investment destination from international investors. The South African Rand ZAR belongs to 20 most traded currencies in the world. In particular, from an economic point of view, we focus on South Africa for the following reasons: Firstly, South Africa presented impressive macroeconomic performance the previous years after a subdued period according to the South African Reserve Bank. Secondly, the recent entrance of South Africa in BRIC countries, as well as the announcement of the establishment of the New Development Bank (NDB) carrying out the objective of the establishment of the Development Bank of the emerging economies, changed this notation into BRICS (Brazil, China, Russia, India and South Africa), thus increasing the country's importance internationally. Thirdly, South Africa exerts major influence on the wider region. What is more, the geographical position of South Africa is in Sub-Saharan Africa. Its economic growth was quite high the previous years. The region still remains a fast-growing country worldwide. Finally, the declining trend in oil prices in recent years influenced greatly competitive economies in the region, such as Nigeria, which is expected to result in a significant influx of investment capital in non-oil producing countries, such as South Africa. ${ }^{1}$ From a financial point of view, the contribution to the existing literature is that we extend previous studies by examining the JSE South African market, which is the oldest and largest market in Africa (see Degiannakis et al. 2010). According to the World Federation of Exchanges (https://www.world-exchanges.org), the JSE belongs to the Major stock exchange groups (top 20 by market capitalization) of issued shares of listed companies.

Against this backdrop, the objective of this paper is to study the predictive ability of economic news releases and macroeconomic determinants on returns, volatility and jumps of the stock and foreign exchange markets of South Africa. The entire analysis is implemented in a monthly frequency. Volatility is estimated with the use of the median realized variance estimator building on the work of Andersen et al. (2012). Jumps are detected and estimated as in Duong and Swanson (2015). The impact of the announcements is assessed building on the work of Huang et al. (2015), by employing a vector autoregressive model with exogenous variables $(V A R-X)$ in order to avoid endogeneity in the estimates. Our results reveal that the macroeconomic fundamentals can explain return, volatility and jumps series. Furthermore, macroeconomic announcements affect significantly both stock and foreign exchange markets. The robustness of results is ensured by examining the research questions in different sub-samples based on the global financial crisis of 2008. Such analysis has important implications for investment managers and policymakers. Our main target is to understand more efficiently the nature of jumpy (known as bad volatility) volatility during periods of macroeconomic adjustments in an emerging but quite promising market. Assuming that policymakers' decisions causing macroeconomic adjustments can create jump-inducing turbulence in financial markets, it is economically vital to progress to an econometric understanding of financial time series behavior of bad and good volatility during such periods (see Todorov and Tauchen 2011). Furthermore, the insights provided in this study are important for the development of hedging strategies and the specification of risk premia. Basically, investors make decisions associated with risk management and designing an appropriate asset allocation strategy. Nevertheless, their decisions can be changed during

1 Continued investments in infrastructure and the increase in consumer spending (due to the rising incomes and rapidly developing economic sectors and particularly services) confirmed these expectations. To the extent that there can be improvement in the global economic climate, Africa is expected to return to its impressive growth performance recorded before the global financial crisis of 2008. 
periods of macroeconomic adjustments and hence could affect the expected risk premia. In light of this, it would be particularly interesting to extend such analysis to other emerging markets-as part of future research-by revisiting the effect of economic news releases and macroeconomic determinants not only on returns and volatility but also by separating volatility into its bad and good components using non-parametric estimators. To our knowledge, this is the first such study.

The remainder of this paper proceeds as follows: Section 2 presents the description of data sources. Section 3 deploys the methodology. Section 4 discusses the empirical findings. Section 5 offers the conclusions.

\section{Data}

The dataset begins on 3 January 2000 and ends on 31 December 2014, for a total of 3906 trading days. Data is obtained from DataStream. South African stock (FTSE/JSE All Share Index) and foreign exchange market (USDZAR) data are in US dollars. ${ }^{2}$ The FTSE/JSE All Share Index is a major stock market index which tracks the performance of all companies listed on the Johannesburg Stock Exchange in South Africa (see Degiannakis et al. 2010). It is a free-float market capitalization weighted index. The FTSE/JSE All Share Index has a base value of 10,815.08 as of 21 June 2002. The USDZAR spot (South African) exchange rate specifies how much one currency, the USD, is currently worth in terms of the other, the ZAR. While the USDZAR spot exchange rate is quoted and exchanged within the same day, the USDZAR forward rate is quoted on a day but its delivery and payment take place on a specific future date. Table $1 \mathrm{~A}$ reports the descriptive statistics of returns, volatility and jumps series of the South African equity market. Table $1 \mathrm{~B}$ reports the descriptive statistics of returns, volatility and jumps series of the South African exchange market.

Quarterly or monthly macrodata series were retrieved from the Economic Outlook Database of the International Monetary Fund in January 2015. The CPI basket was revised in January 2013. The decisions on interest rates are taken by the South African Reserve Bank's Monetary Policy Committee (MPC). The official interest rate is the repo-rate. This is the rate at which central banks lend or discount eligible paper for deposit money banks, typically shown on an end-of-period basis. Since 2012, South Africa has been posting trade deficits mainly due to higher imports of fuel and high-value added goods, while exports have been hurt by several strikes in key mining sectors. In 2013, the biggest trade deficits of South Africa were recorded in its relation to Saudi Arabia, China, India, Germany and Nigeria and the biggest trade surpluses in relation to Botswana, Namibia, Zambia, Mozambique, Zimbabwe, the Netherlands and the United States. Standard \& Poors credit rating for South Africa stands at BBB. Moodys rating for South Africa sovereign debt is Baa1. Fitchs credit rating for South Africa is $\mathrm{BBB}+$. In general, a credit rating is used by sovereign wealth funds, pension funds and other investors to gauge the credit worthiness of South Africa, thus having a big impact on the country's borrowing costs. We group South African economic news releases into three groups of announcements. Table 2 reports the statistical description of each dummy variable. News releases are retrieved from the economic calendar of the Trading Economics. For robustness purposes, news releases are cross-checked with the economic calendar of the FXStreet and several South African news providers.

2 The abbreviations of stock indices are the same as the country's abbreviations. 
Table 1. (A) Descriptive statistics of returns, volatility and jumps series of the South African stock market; (B) descriptive statistics of returns, volatility and jumps series of the South African foreign exchange market.

\begin{tabular}{|c|c|c|c|c|c|}
\hline \multicolumn{6}{|c|}{ (A) } \\
\hline & Mean & St. Deviation & Skewness & Kurtosis & JB Test \\
\hline & \multicolumn{5}{|c|}{ Panel A. Returns } \\
\hline All & 0.00024 & 0.00483 & 0.18821 & 4.11 & 9.59 \\
\hline Pre_crisis & 0.00071 & 0.00531 & 0.05482 & 4.28 & 6.63 \\
\hline \multirow[t]{2}{*}{ Post_crisis } & -0.00039 & 0.00412 & 0.2552 & 2.46 & 1.62 \\
\hline & \multicolumn{5}{|c|}{ Panel B. Volatility } \\
\hline All & 0.0011 & 0.0015 & 3.68 & 21.50 & 2760.19 \\
\hline Pre_crisis & 0.0013 & 0.00168 & 3.668 & 19.41 & 1293.39 \\
\hline \multirow[t]{2}{*}{ Post_crisis } & 0.00082 & 0.00107 & 2.18 & 7.45 & 115.19 \\
\hline & \multicolumn{5}{|c|}{ Panel C. Jumps } \\
\hline All & $-2.66 \times 10^{5}$ & 0.000129 & -0.0326 & 4.39 & 13.54 \\
\hline Pre_crisis & $-3.55 \times 10^{5}$ & 0.00014 & 0.0596 & 3.65 & 1.72 \\
\hline Post_crisis & $-1.46 \times 10^{5}$ & 0.000108 & -0.0681 & 6.27 & 31.67 \\
\hline \multicolumn{6}{|c|}{ (B) } \\
\hline & Mean & St. Deviation & Skewness & Kurtosis & JB Test \\
\hline & \multicolumn{5}{|c|}{ Panel A. Returns } \\
\hline All & 0.00028 & 0.0027 & -0.0263 & 5.41 & 40.41 \\
\hline Pre_crisis & 0.0002 & 0.0032 & 0.0301 & 4.94 & 15.20 \\
\hline \multirow[t]{2}{*}{ Post_crisis } & 0.00039 & 0.0021 & -0.0699 & 2.23 & 1.81 \\
\hline & \multicolumn{5}{|c|}{ Panel B. Volatility } \\
\hline All & 0.00081 & 0.00119 & 4.62 & 29.69 & 5552.27 \\
\hline Pre_crisis & 0.0011 & 0.0015 & 3.69 & 19.06 & 1251.13 \\
\hline \multirow[t]{2}{*}{ Post_crisis } & 0.00041 & 0.00038 & 2.57 & 10.89 & 263.28 \\
\hline & \multicolumn{5}{|c|}{ Panel C. Jumps } \\
\hline All & $5.37 \times 10^{6}$ & 0.0001 & 1.02 & 8.01 & 203.88 \\
\hline Pre_crisis & $5.97 \times 10^{6}$ & 0.00012 & 0.916 & 6.33 & 57.77 \\
\hline Post_crisis & $4.57 \times 10^{6}$ & $7.07 \times 10^{5}$ & 1.12 & 10.6 & 185.89 \\
\hline
\end{tabular}

Notes. Table 1A presents the descriptive statistics (mean, standard deviation, skewness, kurtosis and JB test statistic) of returns, volatility and jumps series of the South African stock market. Table 1B presents the descriptive statistics (mean, standard deviation, skewness, kurtosis and JB test statistic) of returns, volatility and jumps series of the South African foreign exchange market (to US dollar).

Table 2. List of economic news releases.

\begin{tabular}{|c|c|c|c|c|}
\hline Symbol & Title & Description & No & Proportion \\
\hline$D_{1}$ & $\begin{array}{l}\text { monetary } \\
\text { policy }\end{array}$ & SARB interest rate decision & 35 & $21 \%$ \\
\hline$D_{2}$ & $\begin{array}{l}\text { macroeconomic } \\
\text { announcements }\end{array}$ & $\begin{array}{l}\text { Gross domestic product, M3 money supply, trade balance, } \\
\text { net and gross gold and forex reserves and Reuters } \\
\text { econometer }\end{array}$ & 49 & $29 \%$ \\
\hline$D_{3}$ & $\begin{array}{c}\text { governmental } \\
\text { policy }\end{array}$ & $\begin{array}{l}\text { producer price index, private sector credit, } \\
\text { unemployment, total new vehicle sales, manufacturing, } \\
\text { purchasing manager index, consumer price index, retail } \\
\text { sales }\end{array}$ & 49 & $29 \%$ \\
\hline$D$ & All & All news releases & 64 & $38 \%$ \\
\hline
\end{tabular}

Notes. Table 2 lists the three different types of economic news releases, their detailed description, the number of releases and the proportion of days with releases compared to the entire sample. 
We perform the analysis in two sub-periods. For robustness purposes, the determinants and the impact of announcements of returns, volatility and jumps of the stock and foreign exchange South African markets applied to different sub-samples because of international economic crises. For robustness purposes, the evaluation of commodities is implemented in two sub-samples. These are: (1) The pre-crisis sub-sample: January, 2000 to August, 2008. This sub-period starts with the expansion of the FED and ECB balance sheet, because of liquidity issues that seized financial markets, following the collapse of Lehman Brothers (see Cukierman 2013). (2) The post-crisis sub-sample: September, 2008 to December, 2014. This sub-period starts after the expansion of the economic crisis up to the end of the sample. It can be considered as the post-crisis sub-period for the purposes of this study.

\section{Methodology}

We assess the direct impact of South African economic news releases with the use of exogenous variables as well, building on the work of Huang et al. (2015) and Gennaioli et al. (2014). The exogenous variables used in this study are: (i) Inflation rate, (ii) stock market capitalization, (iii) GDP (gross domestic product), (iv) trade integration and (v) interest rate. Quarterly or monthly macrodata series were retrieved from the Economic Outlook Database of the International Monetary Fund in October 2014..$^{3}$ Trade integration is measured as the ratio of international trade (imports plus exports) of a country over the country's GDP.

For our study, we employ ${ }^{4}$ a vector autoregressive model with exogenous variables (VAR-X) described as follows:

$$
Y_{t}=C+\sum_{i=1}^{p} \Phi_{i} \cdot Y_{i, t-1}+\Psi \cdot D_{i, t}+A \cdot I N F L_{t}+B \cdot M C_{t}+\Gamma \cdot G D P_{t}+\Delta \cdot I T_{t}+Z \cdot I N T_{t}+e_{t}
$$

where $Y_{t}$ can be (i) return, (ii) volatility or (iii) jumps series of the South African stock and foreign exchange series in time $t$ (in months) and (i) inflation rate (INFL $\left.L_{t}\right)$, (ii) gross domestic product $\left(G D P_{t}\right)$ or (iii) interest rate $\left(I N T_{t}\right)$ expressed at their first differences. The dummy variable $(D i, t)$ can be any of the following four categories: (i) The monetary policy (SARB interest rate decision) $\left(D_{1}\right)$, when $Y_{t}$ is $I N T_{t}$, (ii) the macroeconomic announcements (gross domestic product, M3 money supply, trade balance, net and gross gold and forex reserves and Reuters econometer) $\left(D_{2}\right)$, when $Y_{t}$ is $G D P_{t}$, (iii) governmental policy news releases (producer price index, private sector credit, unemployment, total new vehicle sales, manufacturing production index, purchasing manager index, consumer price index and retail sales) $\left(D_{3}\right)$, when $Y_{t}$ is $I N F L_{t}$ and (iv) all South African economic news releases together $(D)$. The exogenous variables are: (i) Inflation rate $\left(I N F L_{t}\right)$, (ii) stock market capitalization $\left(M C_{t}\right)$, (iii) gross domestic product $\left(G D P_{t}\right)$, (iv) trade integration $\left(I T_{t}\right)$ and (v) interest rate $\left(I N T_{t}\right)$ expressed at their first differences, by excluding the corresponding exogenous variable for the estimation when it coincides with the dependent variable. By applying this model, we are able to capture significant contemporaneous influences and avoid endogeneity that is likely to exist in the previous equation. The number of lags was selected according to AIC.

Monthly volatility series are estimated via the median realized variance, $\left(M R V_{t}\right)$, building on the study by Andersen et al. (2012) and is described as follows:

$$
M R V_{t}=\frac{22}{22-2} \cdot \sum_{i=2}^{22-1} \operatorname{med}\left(\left|R_{t, i-1}\right|,\left|R_{t, i}\right|,\left|R_{t, i+1}\right|\right)
$$

\footnotetext{
3 As for quarterly data, we apply a linear interpolation to obtain monthly frequency.

4 Following the suggestions of an anonymous referee.
} 
where $R_{t, i}$ is the daily logarithmic return for $i$ day within month $t$ and $l=1, \ldots, N$ is the total number of daily observations within a month (on average the number of daily observations is twenty one). The properties of monthly volatility have been studied in Gkillas et al. (2018d), among others.

The determinants of monthly jumps are also examined as in Gkillas et al. (2018b); Gkillas et al. (2018c) and Gkillas et al. (2019), among others. Jumps are detected as in Bekaert and Hoerova (2014), with the threshold bipower variaton $\left(T B P V_{t}\right)$, which is employed as a jump-free volatility estimator:

$$
\operatorname{TBP} V_{t}=\sum_{i=2}^{22}\left|R_{t, i-1}\right| \cdot\left|R_{t, i}\right| \cdot I_{\left|R_{t, i-1}\right|^{2} \leq \vartheta_{i-1}} \cdot I_{\left|R_{t, i}\right|^{2} \leq \vartheta_{i}}
$$

where $I_{\{\cdot\}}$ is the indicator function and the threshold function. $R_{t, i}$ is the daily return series and $t$ is time in months. Following Duong and Swanson (2015), the jumps statistic is given by:

$$
Z J_{t}^{(T B P V)}=\sqrt{22} \cdot \frac{\left(R V_{t}-T B P V_{t}\right) R V_{t}^{-1}}{\left(\left(\xi_{1}^{-4}+2 \xi_{1}^{-2}-5\right) \max \left\{1, T Q_{t} T B P V_{t}^{-2}\right\}\right)^{1 / 2}}
$$

where $R V_{t}$ is the medial realized volatility $\left(M R V_{t}\right)^{5}$ and $T Q_{t}$ is the realized tripower quarticity which is $T Q_{t}=22 \cdot \xi_{4 / 3}^{-3} \cdot \sum_{i=1}^{22}\left|R_{t, i}\right|^{4 / 3}\left|R_{t, i+1}\right|^{4 / 3}\left|R_{t, i+2}\right|^{4 / 3}$ and converges in probability to integrated quarticity. The $Z J_{t}^{(T B P V)}$ statistic follows standard normal distribution. A jump is considered to be significant if the test statistic exceeds the appropriate critical value of the standard normal distribution denoted by $\Phi_{\alpha}$, at $\alpha$ level of significance; a 95\% significance level is employed. ${ }^{6}$ The jump component of volatility is:

$$
J_{t}^{(T B P V)}=\left[R V_{t}-T B P V_{t}\right] \times I\left[Z J_{t}^{(T B P V)}>\Phi_{a}\right]
$$

where $I[\cdot]$ is the indicator function of the $Z J_{t}^{(T B P V)}$ statistic in excess of a given critical value of the Gaussian distribution $\phi_{a}$. The summation of the squared jump component and the continuous component of the $R V_{t}$ estimator equals to volatility ( $M R V_{t}$ in this study).

\section{Empirical Results}

The results of the impact of the South African economic news releases on South African stock and foreign exchange markets on monthly returns, volatility and jumps series of the South African foreign exchange market are presented on Panel A of Table 3 for the equity market and in Panel $B$ of Table 3 for the exchange market. Table 4A,B indicate the impact of the determinants on monthly returns, volatility and jumps series.

5 The $R V_{t}$ is employed in the jumps detection scheme in order to comply with the literature.

6 There are not significant changes in intensity and magnitude of volatility jumps for a $99 \%$ significance level. 
Table 3. The impact of announcements on monthly returns, volatility and jumps series of the South African stock and foreign exchange (to US dollars) markets.

\begin{tabular}{|c|c|c|c|c|c|c|c|c|c|c|c|c|}
\hline & & $D$ & & & $D_{1}$ & & & $D_{2}$ & & & $D_{3}$ & \\
\hline & Returns & Volatility & Jumps & Returns & Volatility & Jumps & Returns & Volatility & Jumps & Returns & Volatility & Jumps \\
\hline & \multicolumn{12}{|c|}{ Panel A. Stock market } \\
\hline All & 0.863 & -1.4633 & $2.2081 * *$ & 0.0002 & -0.1257 & $1.3345^{* *}$ & 0.6078 & $-0.0037 * *$ & -0.2256 & $1.3188^{*}$ & $-1.8391 * *$ & -0.8589 \\
\hline Pre_crisis & 0.0014 & -0.0005 & $6.16 \times 10^{6}$ & 0.0011 * & -0.0005 & $5.48 \times 10^{5}$ & 0.0029 & -0.0327 * & $2.78 \times 10^{5}$ & $-4.42 \times 10^{5}$ & 0.023 & 0.0004 \\
\hline \multirow[t]{2}{*}{ Post_crisis } & 0.0004 & 0.0001 & 0.0001 & -0.0002 & 0.0001 & $3.09 \times 10^{5 * *}$ & 0.0006 & 0.0002 & $2.87 \times 10^{5}$ & 0.00176 & -0.0022 & $-4.42 \times 10^{5}$ \\
\hline & \multicolumn{12}{|c|}{ Panel B. Foreign exchange market } \\
\hline All & 0.4128 & -0.8463 & -0.0445 & 0.2091 & -0.3236 & 0.6165 & -0.2611 & $0.6129 *$ & -0.03137 & -0.5734 & $1.1391 *$ & 0.0459 \\
\hline Pre_crisis & 0.0006 & -0.0006 & $-1.25 \times 10^{5}$ & 0.0005 & $-0.0006^{* *}$ & $-1.17 \times 10^{5}$ & 0.6400 & 0.0021 & $-6.55 \times 10^{5}$ & $-3.91 \times 10^{6}$ & $-4.11 \times 10^{6}$ & $-1.02 \times 10^{4}$ \\
\hline Post_crisis & 0.0003 & -0.0001 & $-2.23 \times 10^{6}$ & 0.0001 & $8.38 \times 10^{5 * *}$ & $1.32 \times 10^{5}$ & -0.0005 & $-3.90 \times 10^{5}$ & $2.92 \times 10^{6}$ & -0.0004 & 0.0002 & $9.23 \times 10^{6}$ \\
\hline
\end{tabular}

Notes. Table 3 reports the impact of announcements on monthly returns, volatility and jumps series of the South African stock and foreign exchange (to US dollars) markets in panels A and $\mathrm{B}$, respectively; * and ${ }^{* *}$ indicate statistical significance at a $10 \%$ and $5 \%$ significance level, respectively. 
Table 4. (A) The impact of determinants of monthly returns, volatility and jumps series of the South African stock market. (B) The impact of determinants of monthly returns, volatility and jumps series of the South African foreign exchange market.

\begin{tabular}{|c|c|c|c|c|c|}
\hline \multicolumn{6}{|c|}{ (A) } \\
\hline & $I N F L$ & $M C$ & GDP & $I T$ & INT \\
\hline & \multicolumn{5}{|c|}{ Panel A. Returns } \\
\hline All & -0.0003 & $0.0028 * *$ & $-0.0001^{* *}$ & $-0.0018 *$ & $-3.03 \times 10^{5}$ \\
\hline Pre_crisis & -0.0008 & $0.0056^{* *}$ & -0.0001 & -0.0012 & -0.0001 \\
\hline \multirow[t]{2}{*}{ Post_crisis } & $0.0002^{*, * *}$ & $0.0002 *$ & -0.0001 & -0.0043 & $-4.97 \times 10^{5}$ \\
\hline & \multicolumn{5}{|c|}{ Panel B. Volatility } \\
\hline All & $-0.0020^{* *}$ & 0.0018 ** & $-2.40 \times 10^{5 * *}$ & $-0.0004^{* *}$ & $2.26 \times 10^{5 * *}$ \\
\hline Pre_crisis & -0.0003 & $0.0028 *$ & $-2.45 \times 10^{5}$ & -0.00065 & $-5.39 \times 10^{7}$ \\
\hline \multirow[t]{2}{*}{ Post_crisis } & $4.84 \mathrm{e}-5^{*, * *}$ & -0.0011 & $-3.95 \times 10^{6}$ & $0.0004 *$ & 0.00015 \\
\hline & \multicolumn{5}{|c|}{ Panel C. Jumps } \\
\hline All & $-5.36 \times 10^{5 * *}$ & $3.98 \times 10^{5 *}$ & $9.29 \times 10^{7 *}$ & $4.12 \times 10^{6}$ & $5.14 \times 10^{7}$ \\
\hline Pre_crisis & $-9.79 \times 10^{5}$ & $0.0002 * *$ & $-1.21 \times 10^{5}$ & $9.47 \times 10^{5 *}$ & $-2.36 \times 10^{5}$ \\
\hline Post_crisis & $-3.83 \times 10^{5 * * *}$ & $-2.5 \times 10^{5}$ & $-3.78 \times 10^{6}$ & -0.0002 & $2.71 \times 10^{5 * * *}$ \\
\hline \multicolumn{6}{|c|}{ (B) } \\
\hline & $I N F L$ & $M C$ & GDP & $I T$ & $I N T$ \\
\hline & \multicolumn{5}{|c|}{ Panel A. Returns } \\
\hline All & $-0.0089^{* *}$ & $-0.0024 *$ & $9.34 \times 10^{5}$ & -0.0006 & $-6.36 \times 10^{5}$ \\
\hline Pre_crisis & -0.001636 & -0.001963 & $0.000164 * *$ & $-0.0003 *$ & -0.0029 \\
\hline \multirow[t]{2}{*}{ Post_crisis } & $0.0019^{*, * *}$ & $-9.73 \times 10^{6}$ & $-2.97 \times 10^{5}$ & -0.0017 & $5.72 \times 10^{5 * *}$ \\
\hline & \multicolumn{5}{|c|}{ Panel B. Volatility } \\
\hline All & $-0.0002^{*, * *}$ & 0.0009 & $-6.34 \times 10^{5 * *}$ & $-8.85 \times 10^{5}$ & $9.03 \times 10^{5}$ \\
\hline Pre_crisis & -0.000316 & $0.001549 * *$ & $-4.75 \times 10^{5 * *}$ & -0.0003 & $0.0012^{* *}$ \\
\hline \multirow[t]{2}{*}{ Post_crisis } & $-1.215 \times 10^{5}$ & -0.0003 & $-2.06 \times 10^{5}$ & $8.63 \times 10^{5}$ & $2.43 \times 10^{6 * *}$ \\
\hline & \multicolumn{5}{|c|}{ Panel C. Jumps } \\
\hline All & $6.17 \times 10^{6 *}$ & $7.92 \times 10^{6 * *}$ & $1.01 \times 10^{6}$ & $-3.42 \times 10^{5}$ & $5.36 \times 10^{6}$ \\
\hline Pre_crisis & $4.68 \times 10^{5 * *}$ & -0.000151 & $9.43 \times 10^{6 * *}$ & $-6.09 \times 10^{5}$ & $2.61 \times 10^{5}$ \\
\hline Post_crisis & $-1.16 \times 10^{5}$ & $-2.34 \times 10^{5}$ & $-1.64 \times 10^{6}$ & $-8.70 \times 10^{6}$ & $3.32 \times 10^{6 * *}$ \\
\hline
\end{tabular}

Notes. Table $4 \mathrm{~A}$ reports the impact of macroeconomic determinants of the monthly returns, volatility and jumps series of the South African stock market in panel A, B and C, respectively. * and ${ }^{* *}$ indicate statistical significance at a $10 \%$ and $5 \%$ significance level, respectively. Table $4 \mathrm{~B}$ reports the impact of macroeconomic determinants of the monthly returns, volatility and jumps series of the South African foreign exchange (to US dollar) market in panels A, B and C, respectively; * and ** indicate statistical significance at a $10 \%$ and $5 \%$ significance level, respectively.

Regarding the results presented in Table 3, for the stock market (Table 3, Panel A), there is evidence that it is more heavily affected by economic events significant to South African economic news. Economic news have a significant impact on monthly jumps series in the total and pre-crisis periods, while monthly returns and volatility seem to be less affected in the same periods. More specifically, the economic announcements on monetary policy $(D 1)$ have the most significant statistical power. For the same market, returns, volatility and jumps series seem to be unaffected by economic announcements $(D)$ and monetary policy $(D 1)$ announcements in the pre- and post-crisis sub periods. However, macroeconomic announcements (D2) and governmental policy news (D3) have an effect on monthly returns and volatility series mostly in the total period under examination. In Panel B of Table 3, we present the results for the foreign exchange market. We observe that economic news have a minimal impact on the foreign exchange market. For this reason, we conclude that the foreign 
exchange market is less affected by economic announcements, with an explanation being that investors focus on different global financial events.

Furthermore, we examine the country-specific macroeconomic fundamentals as determinants on monthly returns, volatility and jumps series. We present the analysis of the impact of the determinants on monthly returns, volatility and jumps series for the South African stock market in Table 4A, while in Table 4B, we present the results for the South African foreign exchange market. There is evidence that the impact of the determinants explains returns, volatility and jumps series particularly in the total period examined for the stock market (Table 4A). The magnitude of macroeconomic fundamentals is more intense in the overall time period. More specifically, the inflation rate (INFL), the monetary policy $(M C)$ and the gross domestic product $(G D P)$ have the most statistically significant impact in all series. Regarding the pre-crisis sub-sample, there are variables with no statistical effect on the specific period, except for the monetary policy $(M C)$, while the inflation rate (INFL) has a statistically significant effect in all series concerning the post-crisis sub-sample.

As for the exchange market (Table 4B), we observe that the magnitude of the macroeconomic determinants is more intense in the overall and pre-crisis periods in all series. In this case, the inflation rate (INFL) and the monetary policy $(M C)$ have the most statistically significant impact for the monthly returns and jump series, particularly in the total period under examination. Moreover, regarding the pre-crisis sub-sample, the gross domestic product has a statistically significant effect in all series, while for the post-crisis sub-sample, the interest rate $(I N T)$ is a determinant with statistically significant impact different from zero in all series.

To sum-up, we find that economic news releases affect significantly both stock and foreign exchange markets. Such findings are consistent with the existing literature. McQueen and Roley (1993); Fleming and Remolona $(1997,1999)$ and Andersen et al. (2007), among others, studied whether economic news releases affect asset prices. These papers have showed strong evidence that macroeconomic announcement do affect asset returns. Furthermore, going one step further, we also find that the release of more precise economic news have a higher impact on returns, volatility and jumps (see Hautsch and Hess 2007). In other words, a strong relationship also exists between economic news. However, this relation differs across the business cycle (see Gilbert 2011).

\section{Conclusions}

We investigate the impact of economic news releases on returns, volatility and jumps series of the stock and foreign exchange markets of South Africa. The effect of macroeconomic determinants is also assessed. The dataset begins on 3 January 2000 and ends on 31 December 2014, for a total of 3906 trading days incorporating various market phases, such as booms and crashes. The entire analysis is implemented in a monthly frequency. For robustness purposes, the impact of economic news releases is assessed in tow sub-periods before and after the global financial crisis. Volatility is estimated with the use of the median realized variance estimator building on the work of Andersen et al. (2012). Jumps are detected and estimated as in Duong and Swanson (2015). The impact of the announcements is assessed building on the work of Huang et al. (2015), by employing a vector autoregressive model with exogenous variables $(V A R-X)$ in order to avoid endogeneity in the estimates. The macroeconomic fundamentals explain return, volatility and jump series sufficiently. Economic news releases affect significantly both stock and foreign exchange markets. However, the stock market is more heavily affected by economic news releases than the foreign exchange market. Such evidence is consistent with the existing literature. That is, the release of more precise economic news have a higher effect on financial markets (see Hautsch and Hess 2007). Furthermore, a strong relationship also exists between economic news but this relationship differs across the business cycle (see Gilbert 2011).

Taking into consideration the recent events concerning the BRICS and the inflow of investment capital in non-oil producing countries from the declining oil prices, the findings of this study have an international interest. In addition, a better understanding of the nature of jumpy volatility during periods of macroeconomic adjustments has various implications for investment managers, international 
investors and policymakers. This fills in a niche part of the literature on the South African economy and financial markets. In particular, investment managers and international investors should also incorporate such evidence into their asset allocation and risk management strategies during periods of jump-inducing turbulence in financial markets due to economic news releases. What is more, an econometric understanding of market participants responses to economic news releases is important for an effective policy intervention framework to limit jump-inducing turbulence in financial markets. In light of this, policymakers should incorporate the results in favor of markets' participants.

Future research may concern alternative methods for assessing the impact of economic news releases and macroeconomic determinants on returns, volatility and jumps. Finally, a limitation of this study is the use of monthly data. Thus, one could also analyze the role of these oil shocks on volatility jumps of equity markets of other developed and developing economic news releases in South African financial markets using high-frequency data estimating daily volatility and volatility jumps.

Author Contributions: Data curation, K.G. and D.V.; Writing—original draft, K.G. and A.T.; Writing一review \& editing, C.F.

Funding: This research received no external funding.

Conflicts of Interest: The authors declare no conflict of interest.

\section{References}

Andersen, Torben G., Dobrislav Dobrev, and Ernst Schaumburg. 2012. Jump-robust volatility estimation using nearest neighbor. Journal of Econometrics 169: 75-93. [CrossRef]

Andersen, Torben G., Tim Bollerslev, Francis X. Diebold, and Clara Vega. 2007. Real-time price discovery in stock, bond and foreign exchange markets. Journal of International Economics 73: 251-77. [CrossRef]

Andersen, Torben G., Nicola Fusari, and Viktor Todorov. 2015. The risk premia embedded in index options. Journal of Financial Economics 117: 558-84. [CrossRef]

Bahloul, Walid, and Rangan Gupta. 2018. Impact of macroeconomic news surprises and uncertainty for major economies on returns and volatility of oil futures. International Economics 156: 247-53. [CrossRef]

Balcilar, Mehmet, Esin Cakan, and Rangan Gupta. 2017. Does US news impact Asian emerging markets? Evidence from nonparametric causality-in-quantiles test. The North American Journal of Economics and Finance 41: $32-43$. [CrossRef]

Baum, Christopher F., Alexander Kurov, and Marketa Halova Wolfe. 2015. What Do Chinese Macro Announcements Tell Us about the World Economy? Journal of International Money and Finance 59: 100-22. [CrossRef]

Bauwens, Luc, Walid Ben Omrane, and Pierre Giot. 2005. News announcements, market activity and volatility in the euro/dollar foreign exchange market. Journal of International Money and Finance 24: 1108-25. [CrossRef]

Bekaert, Geert, and Marie Hoerova. 2014. The VIX, the variance premium ans stock market volatility. Journal of Econometrics 183: 181-92. [CrossRef]

Boudoukh, Jacob, Matthew Richardson, YuQing Shen, and Robert F. Whitelaw. 2007. Do asset prices reflect fundamentals? Freshly squeezed evidence from the FCOJ market. Journal of Financial Economics 83: 397-412. [CrossRef]

Cakan, Esin. 2012. The Business Cycle And Impacts Of Economic News On Financial Markets. Journal of Business E Economics Research (JBER) 10: 385. [CrossRef]

Cakan, Esin, Nadia Doytch, and Kamal P. Upadhyaya. 2014. Does macrodata Macroeconomic News Make Emerging Financial Markets Riskier? Borsa Istanbul Review 15: 37-43. [CrossRef]

Cukierman, Alex. 2013. Monetary policy and institutions before, during, and after the global financial crisis. Journal of Financial Stability 9: 373-84. [CrossRef]

Degiannakis, Stavros, and Christos Floros. 2010. Hedge Ratios in South African. Journal of Emerging Market Finance 9: 285-304. [CrossRef]

De Pooter, Michiel, Patrice T. Robitaille, Ian Walker, and Michael Zdinak. 2014. Are long-term inflation expectations well anchored in Brazil, Chile and Mexico? International Journal of Central Banking 10: 337-400. [CrossRef] 
Duong, Diep, and Norman R. Swanson. 2015. Empirical evidence on the importance of aggregation, asymmetry, and jumps for volatility prediction. Journal of Econometrics 187: 606-21. [CrossRef]

Elder, John, Hong Miao, and Sanjay Ramchander. 2012. Impact of macroeconomic news on metal futures. Journal of Banking \& Finance 36: 51-65.

Esin, Cakan, and Rangan Gupta. 2017. Does the US macroeconomic news make the South African stock market riskier? The Journal of Developing Areas 51: 15-27. [CrossRef]

Finnerty, John D., Cameron D. Miller, and Ren-Raw Chen. 2013. The impact of credit rating announcements on credit default swap spreads. Journal of Banking and Finance 37: 2011-30. [CrossRef]

Fiordelisi, Franco, Giuseppe Galloppo, and Ornella Ricci. 2014. The effect of monetary policy interventions on interbank markets, equity indices and GSIFIs during financial crisis. Journal of Financial Stability 11: 49-61. [CrossRef]

Fleming, Michael J., and Eli M. Remolona. 1997. What Moves the Bond Market? Economic Policy Review. New York: Federal Reserve Bank of New York, pp. 31-50.

Fleming, Michael J., and Eli M. Remolona. 1999. Price formation and liquidity in the U.S. treasury market: The response to public information. Journal of Finance 54: 1901-15. [CrossRef]

Gennaioli, Nicola, Alberto Martin, and Stefano Rossi. 2014. Sovereign default, domestic banks, and financial institutions. Journal of Finance 69: 819-66. [CrossRef]

Gilbert, Thomas. 2011. Information aggregation around macroeconomic announcements: Revisions matter. Journal of Financial Economics 101: 114-31. [CrossRef]

Gkillas, Konstantinos, Rangan Gupta, and Mark E. Wohar. 2018a. Volatility jumps: The role of geopolitical risks. Finance Research Letters 27: 247-58. [CrossRef]

Gkillas, Konstantinos, Dimitrios I. Vortelinos, and Tahir Suleman. 2018b. Asymmetries in the African Financial markets. Journal of Multinational Financial Management 45: 72-87. [CrossRef]

Gkillas, Konstantinos, Gideon Boako, Dimitrios Vortelinos, and Lavrentios Vasiliadis. 2018c. Non-parametric quantile dependencies between volatility discontinuities and political risk. Finance Research Letters [CrossRef]

Gkillas, Konstantinos, Dimitrios I. Vortelinos, and Shrabani Saha. 2018d. The properties of realized volatility and realized correlation: Evidence from the Indian stock market. Physica A: Statistical Mechanics and Its Applications 492: 343-59. [CrossRef]

Gkillas, Konstantinos, Rangan Gupta, and Mark E. Wohar. 2019. Oil shocks and volatility jumps. Review of Quantitative Finance and Accounting 1-26. [CrossRef]

Gupta, Rangan, and Monique Reid. 2013. Macroeconomic surprises and stock returns in South Africa. Studies in Economics and Finance 30: 266-82. [CrossRef]

Hashimoto, Yuko, and Takatoshi Ito. 2010. Effects of Japanese macroeconomic statistic announcements on the dollar/yen exchange rate: High-resolution picture. Journal of the Japanese and International Economies 24: 334-54. [CrossRef]

Hausman, Joshua, and Jon Wongswan. 2011. Global asset prices and FOMC announcements. Journal of International Money and Finance 30: 547-71. [CrossRef]

Hautsch, Nikolaus, and Dieter Hess. 2007. Bayesian learning in financial markets: Testing for the relevance of information precision in price discovery. Journal of Financial and Quantitative Analysis 42: 189-208. [CrossRef]

Huang, Tao, Fei Wu, Jing Yu, and Bohui Zhang. 2015. International political risk and government bond pricing. Journal of Banking and Finance 55: 393-405. [CrossRef]

Kenourgios, Dimitris, Stephanos Papadamou, and Dimitrios Dimitriou. 2015. On quantitative easing and high frequency exchange rate dynamics. Research in International Business and Finance 34: 110-25. [CrossRef]

Li, Junye, and Gabriele Zinna. 2018. The Variance Risk Premium: Components, Term Structures, and Stock Return Predictability. Journal of Business and Economic Statistics 36: 411-25. [CrossRef]

Marshall, Andrew, Taleh Musayev, Helena Pinto, and Leilei Tang. 2012. Impact of news announcements on the foreign exchange implied volatility. Journal of International Financial Markets, Institutions \& Money 22: 719-37.

McQueen, Grant, and V. Vance Roley. 1993. Stock prices, news, and business conditions. Review of Financial Studies 6: 683-707. [CrossRef]

Nowak, Sylwia, Jochen Andritzky, Andreas Jobst, and Natalia Tamirisa. 2011. Macroeconomic fundamentals, price discovery, and volatility dynamics in emerging bond markets. Journal of Banking E Finance 35: 2584-97.

Ricci, Ornella. 2015. The impact of monetary policy announcements on the stock price of large European banks during the financial crisis. Journal of Banking and Finance 52: 245-55. [CrossRef] 
Rosa, Carlo. 2011. Words that shake traders. The stock markets reaction to central bank communication in real time. Journal of Empirical Finance 18: 915-34. [CrossRef]

Santa-Clara, Pedro, and Sun Yan. 2010. Crashes, Volatility, and the Equity Premium: Lessons from S\& P 500 Options. Review of Economics and Statistics 92: 435-51.

Shaikh, Imlak, and Puja Padhi. 2013. The Information Content of Implied Volatility Index (India VIX). Global Business Perspectives 1: 359-78. [CrossRef]

Shu, Chang, Dong He, Jinyue Dong, and Honglin Wang. 2018. Regional pull vs global push factors: China and US influence on Asian financial markets. Journal of International Money and Finance 87: 112-32. [CrossRef]

Todorov, Viktor, and George Tauchen. 2011. Volatility jumps. Journal of Business E Economic Statistics 29: 356-71.

Vortelinos, Dimitrios I., and Konstantinos Gkillas. 2018. Intraday realised volatility forecasting and announcements. International Journal of Banking, Accounting and Finance 9: 88-118. [CrossRef]

(C) 2019 by the authors. Licensee MDPI, Basel, Switzerland. This article is an open access article distributed under the terms and conditions of the Creative Commons Attribution (CC BY) license (http:/ / creativecommons.org/licenses/by/4.0/). 